\title{
METHODS OF THE FORMATION OF NEW WORDS IN THE RUSSIAN LANGUAGE OF THE XVIII CENTURY: NEOLOGISMS IN THE TEXTS OF CATHERINE II
}

\author{
Alena Ju. Nikitina ${ }^{1}$, Margarita V. Emelianova ${ }^{2}$, Olga A. Petrova ${ }^{3}$, Tatyana N. \\ Romanova $^{4}$, Anzhelika G. Abramova ${ }^{5}$, Irina N. Anisimova ${ }^{6}$ \\ ${ }^{1}$ Assoc. Prof., Chuvash State University, RUSSIA, alyona.nikitina@gmail.com \\ ${ }^{2}$ Assoc. Prof., Chuvash State University, RUSSIA, marg_emel@yahoo.com \\ ${ }^{3}$ Assoc. Prof., Chuvash State University, RUSSIA, zadumka@mail.ru \\ ${ }^{4}$ Assoc. Prof., Chuvash State University, RUSSIA, romanovatn1@mail.ru \\ ${ }^{5}$ Assoc. Prof., Chuvash State University, RUSSIA, foreign-languages-department@mail.ru \\ ${ }^{6}$ Assoc. Prof., Chuvash State University, RUSSIA, anirin82@mail.ru
}

\begin{abstract}
The article is devoted to the analysis to the study of neologisms as an integral part of texts of different genres written by Catherine II. The problem is considered to be urgent as it can be useful for the study of history and historical processes in the Russian language, for to description of the linguistic-cognitive level of the linguistic personality of the empress, her picture of the world. The authors studies the reasons of the emergence of neologisms the texts of Catherine the Great, reveals the reasons that affected their usage in the texts. The authors studies the ways of neologisms formation. The concept of the term "stylistic neologism" is considered and the classification of methods of formation of the words is given. Suffixation, prefixation and stem composition methods are described as the most widely used ways for the neologisms to be formed. A productive way to form adjectives in the works of Catherine II is suffixation (suffixes -лив-, тельн-). Suffixes -ниц-, -льниц-, -ство- are the most common productive way to form nouns. New verbs are formed by adding to the abstract or concrete noun the word-derivative suffix typical for verbs -ирова-. The desire of Catherine the Great for emotionality leads to creating of a large number of words with diminutive suffixes -ечк-, -еньк-, -оньк-, -ушк-, -юшк-. It is revealed that the individual stylistic neologisms of the empress-writer help Catherine the Great to characterize an object or phenomenon better, to emphasize the conceptual element, quality and ideological concept of the created word, necessary in a certain communicative situation.
\end{abstract}

Keywords: neologism, linguistic-cognitive level, linguistic personality, linguistic picture of the world, word formation

\section{INTRODUCTION}

In the works of Catherine II, together with common occasional phrases and expressions there are a lot of individually-used words, it is a kind of individually stylistic neologisms of the Empress-writer. When we speak about stylistic neologism, we mean neologism (word or speech), "created by the author of this literary work with a specific stylistic purpose and usually not widely used, not included in the vocabulary of the language" (Rosenthal, 2003, p. 223). In our opinion, such wordshelp Catherine the Great to characterize better an object or phenomenon, show its essence, emphasize the conceptual element, quality, ideological concept of 
an educated language unit, necessary in a certain communicative situation.

The aim of the study is to identify the main ways of forming new words in the Russian language of the XVIII century on the basis of texts of Catherine II.

To achieve this aim it is necessary to solve the following tasks:

1) To identify the main goals of creating neologisms by Catherine the Great;

2) To determine the most productive ways of forming new words: nouns, adjectives, verbs, adverbs, etc.

Our analysis of the texts written by Catherine II identified that neologisms are created by the Empress using several quite productive ways.

\section{RESULTS}

\subsection{The formation of Adjectives}

A productive way to form adjectives in the works of Catherine II is a suffix.

1) Adjectives which are used to characterize a person or give a more detailed description of a situation are formed from nouns denoting a particular phenomenon or object using the suffix (primarily the suffix -лив-).

"Всякий это и говорит; а он урочлив, мой свет, так урочлив, что нельзя больше" (comedy Oh, Times!). The adjective урочлив is used to characterize the son of the hero Chudikhin, who receives many lessons from all the people surrounding him. Consequently, the word урочлив acts as a suffix formation from a noun lesson.

2) Adjectives are formed from verbs by adding the suffix -тельн-.

In the study of I.M. Maltseva "Lexical new formations in the Russian language of the XVIII century" (1975), it is noted that "in the XVIII century in the field of verbal word formation of adjectives the suffix -тельнbelonged to the number of the most active and productive" (Maltseva, 1975, p. 210). According to linguists the intensification of its use is caused by the expansion of their word-formation base and the increase in the semantic capacity of this word-formation type (Maltseva, 1975, p.212). In the texts of Catherine II there are both qualitative and relative adjectives formed using the suffix -тельн- from verbs of different semantics abstract and concrete (denoting specific physical actions): for example, охранительный, помогательный, отвечательный, примирительный, приседательный, отвлекательный, излечительное, умяхчительный.

«Лекарство дать ей должно, я для того мы здесь; но избрать из сотни помогательное на тот случай, в том искусство состоuт» (comedy The Deceiver). The noun помогательное is formed from the verb помогать, and помогательное is smth "what should help".

From adjectives formed with the suffix -тельн- Catherine the Great also creates adverbs: «Cтрасть кистью своей дьлаеть начертанія на лиць всякаго человька; веселье, радость, сердие, печаль, ревность, зависть, ложь, мщеніе, нерьшимость, твердость, упрямство - дьйствують снаружи; черты онымъ соотвьтствуютъ протягательно, или укротительно, или отпускательно, или замьшательно, или инако» (comedy Siberian Shaman).

\subsection{The formation of Nouns}

Nouns denoting an object of action or subject are formed from verbs in a suffix way. The most often used suffixes are -ниц-, -льниц-, -ство-:

«Мадам Грибуж держит ей под носом нюхальницу» (comedy The Deceiver). The noun нюхальницу is formed by the suffix method (suffix -льниц-) from the verb нюхать and denotes an object that is sniffed, inhaled. However, the researcher E. Epstein singles out the suffix -аль-, calling it one of the most common in the 14-18 centuries (Epstein).

In the work of I.M. Maltseva "Lexical new formations in the Russian Language of the 18th century" (1975), it is rightly noted that nouns formed by the addition of the element -ство- were widespread in the texts of the 18th century, and lexemes of various lexical and semantic categories could be highlighted among them: a) with the value of quality, property, attribute, b) with the value of the abstract action, c) with the value of the state, d) the collective value, e) with the specific value (Maltseva, 1975, p. 79). In the works of Catherine the Great, words with the suffix -ство- dominate, having a collective meaning, as well as reflecting properties, states, phenomena of reality: лицеимство, обезьянство, спокойство, самодержавство, пріятство, покорство, земледельство, насильство. 
Nouns are formed by joining so-called diminutive suffixes (suffixes of subjective assessment) to abstract nouns, and new words start to have an ironic connotation of meaning:

«Нет ли любовишки?» (comedy "Siberian Shaman"). In this way in the comedy "Siberian Shaman" the main hero Bragin with irony says about the causes of poor health.

\subsection{Ways to Create Verbs and Verbal Lexemes}

1) New verbs are formed by adding to the abstract or concrete noun a word-forming suffix -ирова-typical for this part of speech:

«Bот еще! стану ли я с такою подлостью анканальироваться и жизнь свою рискировать!» (the comedy On the name-day of Madame Vorchalkina). The verb рискировать is formed from the word риск with the help of the productive verb suffix -ирова-. The word анканальироваться is formed from "каналья" in a confix way (prefix -ан-, suffix -ирова-).

2) In the works of Catherine II, a productive word-formation element (suffix) -ирова- is often joined to foreign verbs because the Empress wanted to use less foreign words: деконтенансировался, крейсировать, реко[2]носировать, ангажировать, супсанировать, шиканирует, англозировалась, суфрлитировать.

3) In the texts written by Catherine II, there are also words formed in the prefixal way, but they are presented in small numbers. And the main function of the prefix is to give the lexeme great emotional richness:

"Только нет, пора перестать тебе дать уверения: ты должен уже быть пре пре преуверен, что я тебя люблю. Вот и вся сказка тут, а сказки иные - не суть сказки" (Letters from Catherine II to Count G. Potemkin). In this example, the repeated prefix was used by Catherine II with a specific communicative task - to emphasize the importance of the absoluteness of the action, the highest degree of the attribute.

\subsection{A Stem Composition}

A productive way of forming lexical units of different parts of speech is a stem composition. Such new formations are very often found in the texts of Catherine II of any genre affiliation and determine the linguistic personality of the empress. She uses such words for various purposes: in some cases to give an ironic meaning, in others to highlight the necessary connotation of meaning in a word.

By adding up the foundations, lexical units of the following parts of speech are formed primarily: noun, adverb and adjective. Verbs created by this method were not found in the analyzed material.

Such words are different in the way they are formed:

1) Model "the adjective + noun": неудобовозможности, высокознание, густомысліе, полномысліе, легковьрностію, тонкомысліе, глубокомысліе, еtс.;

2) Model "noun + noun": умоначертание, огнестрелие, etc.;

3) Model "adjective + adjective": краткодлинная, высокоумнаго, высокотонкие, etc.;

4) Model "adverb + adjective (verb adjective)": противонелепый, новопринятымъ, etc.;

5) Model "numeral + adverb": двоесмысленно, etc.;

6) Model "numeral + adjective (or noun)": двоезнаменательныя, премноготрудный, трилистный, тригоднешная, еtc.;

7) model "noun + verb": головоломнаго, etc.

\subsection{Suffixes of Subjective Assessment}

An exceptional feature of the linguistic personality of Catherine II is the way of formation of new lexical units of different parts of speech by adding diminutive and caressing suffixes (suffixes of subjective assessment) ечк-, -еньк-, -оньк-, -ушк-, -юшк-, etc. The largest number of words created in this way is found in the letters of the empress addressed to her favorite Count G.A. Potemkin, due to the special feelings of Catherine the Great to this person, as well as in literary works (comedies, fairy tales). With the help of diminutive suffixes, words of various parts of speech are formed:

1) Nouns: хандрушечка, милюшечка, словечушко, сударушка, сердечишко, крошечко, личико, слезки, веревочка, еtc.;

2) Adjectives: миленький, добренькое, свеженькие, молодешенька, etc.;

3) Adverbs: изряднешенько, умненько, хорошохонько, малешенько, еtc. 


\section{CONCLUSIONS}

The creation of words is one of the most important methods of the linguistic personality of Catherine II. The purpose of individual author's new formations is to emphasize the conceptual element necessary in a certain communicative situation, the quality, the meaning of a linguistic unit, necessary in a certain context.

\section{REFERENCE LIST}

Epstein, E. The Gift of Word. Projective Dictionary of the Russian Language. http://www.emory.edu/INTELNET/dar242.htm

Maltseva, I.M. (1975) Lexical new formations in the Russian language of the XVIII century. Leningrad: Nauka.

Rosenthal, D.E. (2003) Handbook of the Russian language. Dictionary of linguistic terms. Moscow: ONIX 21 Century Publishing House LLC: Mir and Education Publishing House LLC. 